\title{
The Multiple Meanings of Open Government Data: Understanding Different Stakeholders and Their
}

\section{Perspectives}

Felipe Gonzalez-Zapata \& Richard Heeks ${ }^{1}$

Centre for Development Informatics, University of Manchester, Manchester, M13 9PL, UK

${ }^{1}$ Corresponding author: Prof. Richard Heeks, Centre for Development Informatics, IDPM, SEED, University of Manchester, Manchester, M13 9PL, UK, +44-161-275-2870

richard.heeks@manchester.ac.uk

This is a post-print, pre-proof version of the following article, which should be used as the citation/reference:

Gonzalez-Zapata, F. \& Heeks, R. (2015) The multiple meanings of open government data: understanding different stakeholders and their perspectives, Government Information Quarterly, 32(4), 441-452

which has been published in final form at: http://dx.doi.org/10.1016/i.giq.2015.09.001 


\begin{abstract}
As a field of practice and research that is fast-growing and a locus for much attention and activity, open government data (OGD) has attracted stakeholders from a variety of origins. They bring with them a variety of meanings for OGD. The purpose of this paper is to show how the different stakeholders and their different perspectives on OGD can be analyzed in a given context. Taking Chile as an OGD exemplar, stakeholder analysis is used to identify and categorize stakeholder groups in terms of their relative power and interest as either primary (in this case: politicians, public officials, public sector practitioners, international organizations) or secondary (civil society activists, funding donors, ICT providers, academics). Stakeholder groups sometimes associated with OGD but absent from significant involvement in Chile - such as private sector- and citizen-users - are also identified.
\end{abstract}

Four different perspectives on open government data - bureaucratic, political, technological and economic - are identified from a literature review. Template analysis is used to analyze text-OGD-related reports, conference presentations, and interviews in Chile - in terms of those perspectives. This shows bureaucratic and political perspectives to be more dominant than the other two, and also some presence for a politico-economic perspective not identified from the original literature review. The information value chain is used to identify a "missing middle" in current Chilean OGD perspectives: a lack of connection between a reality of data provision and an aspiration of developmental results. This pattern of perspectives can be explained by the capacities and interests of key stakeholders, with those in turn being shaped by Chile's history, politics and institutions.

Overall, stakeholder analysis and perspectives analysis are shown from this case to be workable techniques for OGD that add value by exposing the identity, power, motivations and worldview of key actors. They provide a necessary foundation of knowledge for both researchers and practitioners who need to understand the different meanings of OGD in any particular context.

Keywords: open government data; stakeholder analysis; perspectives analysis; Chile 


\section{Introduction}

From origins in Freedom of Information up to the present day, there is growing practice of open government data (OGD) initiatives around the world, with a particular expansion during the 2010s. This has occurred within individual governments such as the US (Obama, 2010) and UK (Cabinet Office, 2012), and has been driven forward by global organizations such as the World Bank (2012) and United Nations (2013) and through the advent of the Open Government Partnership (OGP, 2015a).

This has therefore become a topic of increasing importance, with a growing level of interest and involvement from policy-makers and practitioners both inside and outside government. Mirroring this growth in practice has been a growth in research and literature on open government data (e.g. Kalampokis, Tambouris, \& Tarabanis, 2011; Luna-Reyes, Bertot, \& Mellouli, 2014; Robinson, Yu, Zeller, \& Felten, 2009; Ubaldi, 2013), even though as yet the overall extent of research and literature on OGD is still quite limited.

Like many fields experiencing rapid growth from small beginnings, open government data has attracted commentators, strategists and practitioners from a variety of origins: "There are a lot of different voices in this space" (Howard, 2012a). They bring with them different understandings and different visions of OGD. At present, these different stakeholders and their different perspectives are not well understood in OGD. This will be a problem for analysts and researchers if they assume those working within the OGD field share common understandings and meanings, when in fact they may not. But it will be even more problematic for practice. We know from existing experience in the related field of egovernment that a failure to identify different stakeholders and their views causes problems for projects and, conversely, that analysis of stakeholder perspectives can make initiatives more effective (Axelsson, Melin, \& Lindgren, 2013; Saebo, Flak, \& Sein, 2011). 
The focal question for this paper is therefore: "What are the multiple meanings ascribed to open government data?". We instantiate this with a specific case study in the context of Chile, which asks three sub-questions:

- Who are the different stakeholders shaping the meaning of OGD in this context?

- What are the different meanings these stakeholders give to OGD in this context?

- Why are the different stakeholders ascribing these particular meanings?

The main contribution of the paper is to help all those working within the field of OGD to understand the different perspectives and motivations of the various other stakeholders who work alongside them on open government data, or whom they research. Conceptually we provide a first application of stakeholder analysis to OGD, and also analysis of perspectives. Alongside assisting OGD researchers, we argue that application of these two analysis techniques will have a practical value in helping improve the likely effectiveness of OGD initiatives. In turn, that greater effectiveness should have a broader social value in delivering the intended political and economic benefits of open government data.

The structure of the paper is as follows. In the next section, there is a literature-based review of the different perspectives that exist on OGD, then followed by an explanation of the research methodology utilized. Findings about key stakeholders in the Chilean context and their perspectives are given next. Finally, the paper offers some explanation of these perspectives and draws conclusions.

\section{Perspectives on Open Government Data}

If, as noted above, an understanding of differing open government data perspectives can make for more effective OGD analysis and practice, how can we identify those perspectives? A starting point will be a reduction of OGD into its three foundations - open, government, and data - as shown in Figure 1 (developed from Howard, 2012a; Yu \& Robinson, 2012). This creates three entry points to OGD:

- Government data approaches originate in government being the single largest collector, user, holder and producer of information about citizens, organizations or public service delivery (Heeks, 2006). A particular concern is with the way in which that data, as a 
resource, can best be managed within the public sector (Otjacques, Hitzelberger, \& Feltz, 2007).

- Open data approaches are not sectorally-bound but originate in the information and communication technology- (ICT-)related innovation and diffusion which potentially enables much greater accessibility of data than previously (Braunschweig, Eberius, Thiele, \& Lehner, 2012). A particular concern is overcoming barriers to this accessibility through innovations in the way data is captured, stored, processed and output (ibid., Janssen \& Zuiderwijk, 2014).

- Open government approaches originate in beliefs that government decision-making and actions should be more transparent and participative (Meijer, Curtin, \& Hillebrandt, 2012). A particular concern has been finding ways to empower citizens individually and organizations of civil society collectively through the process of opening government (Lathrop \& Ruma, 2010).

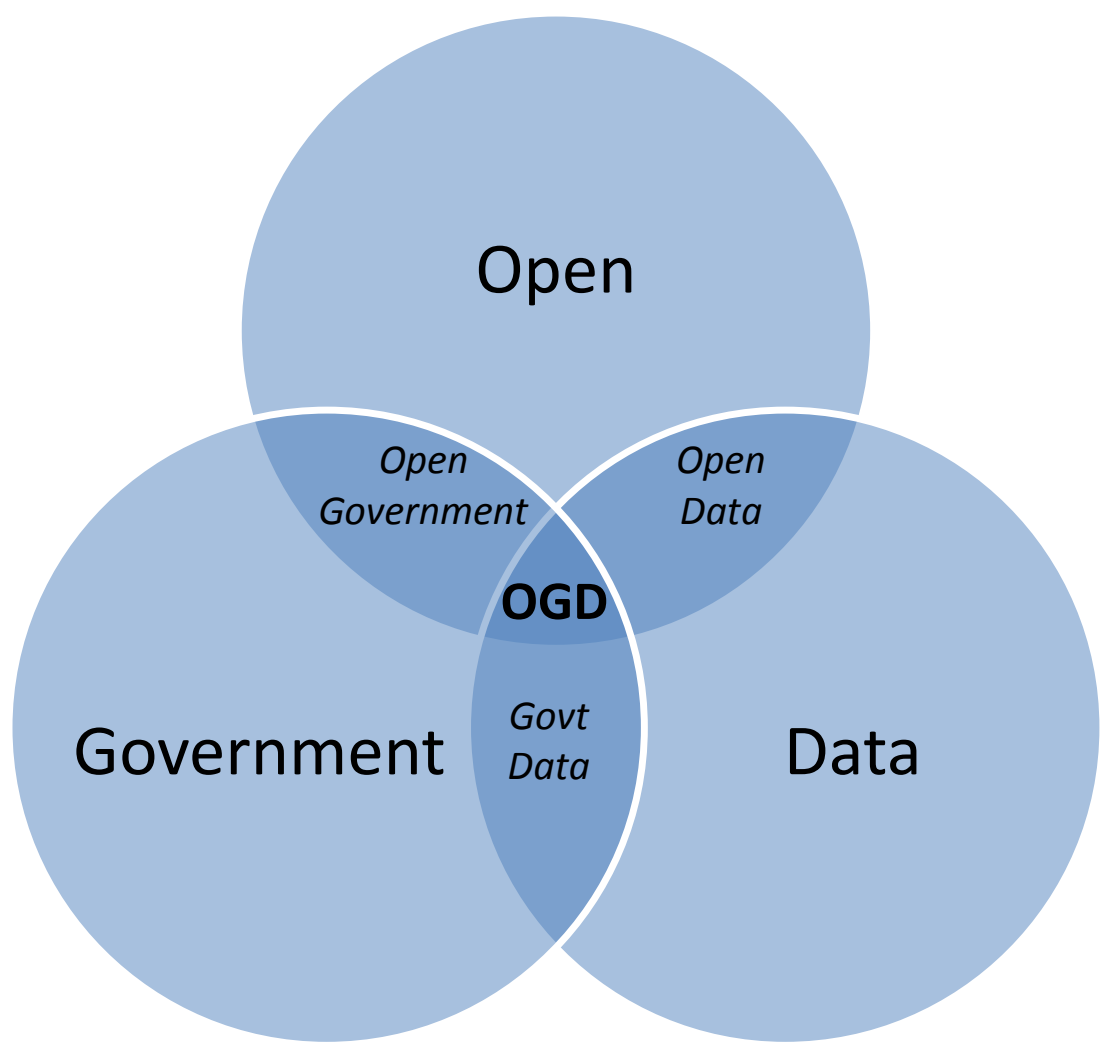

Figure 1: Foundations of Open Government Data 
Taking these three different approaches as our foundation, we then began an iterative process of comparing the approaches with the views expressed in literature on open government data. That literature was identified via search term "open government data" starting with more highly-cited items but filtered to focus on sources in which differing perspectives were discussed; derived either in relation to OGD practice or to OGD conceptualization (for example, Davies, 2010; Huijboom \& van den Broek, 2011; Janssen, Charalabidis, \& Zuiderwijk, 2012; Ubaldi, 2013 plus sources cited below). We continued the iterative process of analyzing literature content, discussing and refining the perspectives, and comparing to further literature content until we reached a saturation point where new literature was not producing any additional refinements to the perspectives. In total, this involved content analysis of just over twenty items of literature, and finally suggested not three but four differing perspectives that may be brought to bear on open government data.

The Bureaucratic Perspective is one closely associated with the ideas of government data. It conceives OGD as a government policy to support public service delivery in terms of the improved manipulation of public sector data (Heusser, 2013). That notion of "improved manipulation" typically focuses on changes undertaken within government by officials and technical staff: regulations, strategies, processes. The intention of those changes is to deliver greater efficiency in the way that data is handled by government, and - through greater openness - to deliver greater efficiency and effectiveness of what are seen to be the core outreach functions of the public sector: its provision of services (Longo, 2011; World Bank, 2012). Opening of government data is also seen to help reduce the cost and improve the quality of internal processes, such as the formation of policy (Concha \& Naser, 2012a, 2012b; Janssen, 2012).

The Technological Perspective is one closely associated with the ideas of open data. It conceives OGD as a technological innovation based around changes undertaken by technical staff in ICTs and around the design of formats, processes and standards that are used to handle public sector data (Ding, Michaelis, McGuinness, \& Hendler, 2010; Kalampokis, Tambouris, \& Tarabanis, 2011; Zuiderwijk \& Janssen, 2012). The intention of those changes is to provide an improved data infrastructure within government, in which data adheres to 
foundational qualities (e.g. accuracy, completeness, timeliness) and also adheres to distributive qualities (e.g. free availability, reusability, interoperability) which allow it to readily be accessed and used by other stakeholders and be integrated with other data sets (Barros, 2011; Kalampokis, Tambouris, \& Tarabanis, 2011; Malmud et al, 2007).

The Political Perspective is one closely associated with the ideas of open government. It conceives OGD as akin to a fundamental right; with inherent social value for all citizens to have access to public sector data (AIE/OKF, 2011; Yu \& Robinson, 2012). The intention of open government data should be better governance: that this data will help improve transparency and accountability of government officials and functions; enable greater participation of citizens and other stakeholders of civil society in public sector decisions such as policy making; and rebalance inequities of power between those inside and those outside government (Janssen, 2012; Kassen, 2013; Raman, 2012).

The Economic Perspective is one that has emerged from the ideas of open government data itself. It conceives OGD as a means to further economic growth through mainly market/private sector firm-based manipulation of public sector data made freely-available (Capgemini Consulting, 2013; Howard, 2012b). The intention of open government data is to facilitate the entrepreneurial creation of new products and services, and to generate further economic value via creation of jobs, profits and investments (Bates, 2012; Elbadawi, 2012; Thompson, 2011).

The four perspectives - for which Table 1 provides a summary - can be used as the basis for investigation of stakeholder views in any particular context. 


\begin{tabular}{|c|c|c|c|}
\hline OGD Perspective & Nature of OGD & $\begin{array}{c}\text { Drivers and Benefits } \\
\text { of OGD }\end{array}$ & Main OGD Actors \\
\hline $\begin{array}{l}\text { Bureaucratic } \\
\text { Perspective }\end{array}$ & $\begin{array}{l}\text { A policy of data } \\
\text { regulations, strategies } \\
\text { and processes within } \\
\text { government }\end{array}$ & $\begin{array}{l}\text { Improvements in } \\
\text { public services } \\
\text { through greater } \\
\text { efficiency and } \\
\text { effectiveness of data } \\
\text { management }\end{array}$ & $\begin{array}{l}\text { Public servants; ICT } \\
\text { staff [operational role] }\end{array}$ \\
\hline $\begin{array}{l}\text { Technological } \\
\text { Perspective }\end{array}$ & $\begin{array}{l}\text { A technological } \\
\text { innovation within } \\
\text { government data } \\
\text { systems }\end{array}$ & $\begin{array}{l}\text { Improved government } \\
\text { data infrastructure }\end{array}$ & $\begin{array}{l}\text { ICT staff [design and } \\
\text { operational roles] }\end{array}$ \\
\hline $\begin{array}{l}\text { Political } \\
\text { Perspective }\end{array}$ & $\begin{array}{l}\text { A right of free access } \\
\text { to public sector data }\end{array}$ & $\begin{array}{l}\text { Better governance } \\
\text { through increased } \\
\text { transparency, } \\
\text { accountability, } \\
\text { participation and } \\
\text { empowerment }\end{array}$ & $\begin{array}{l}\text { Citizens } \\
\text { [user/beneficiary role] }\end{array}$ \\
\hline $\begin{array}{l}\text { Economic } \\
\text { Perspective }\end{array}$ & $\begin{array}{l}\text { A mechanism to } \\
\text { generate data-based } \\
\text { economic value }\end{array}$ & $\begin{array}{l}\text { Economic value } \\
\text { through new products, } \\
\text { services, revenue, } \\
\text { profits and jobs }\end{array}$ & $\begin{array}{l}\text { Private sector firms, } \\
\text { entrepreneurs } \\
\text { [user/beneficiary role] }\end{array}$ \\
\hline
\end{tabular}

Table 1: Derived Perspectives on Open Government Data

\section{Research Methodology}

In order to understand the multiple meanings ascribed to open government data in any particular context, we need to analyze: who is involved with OGD in that context; and what their particular perspectives are on OGD. Our overall method is summarized in Figure 2 and the remaining steps (some of "Step 0" has already been covered in the previous section) are described below. 


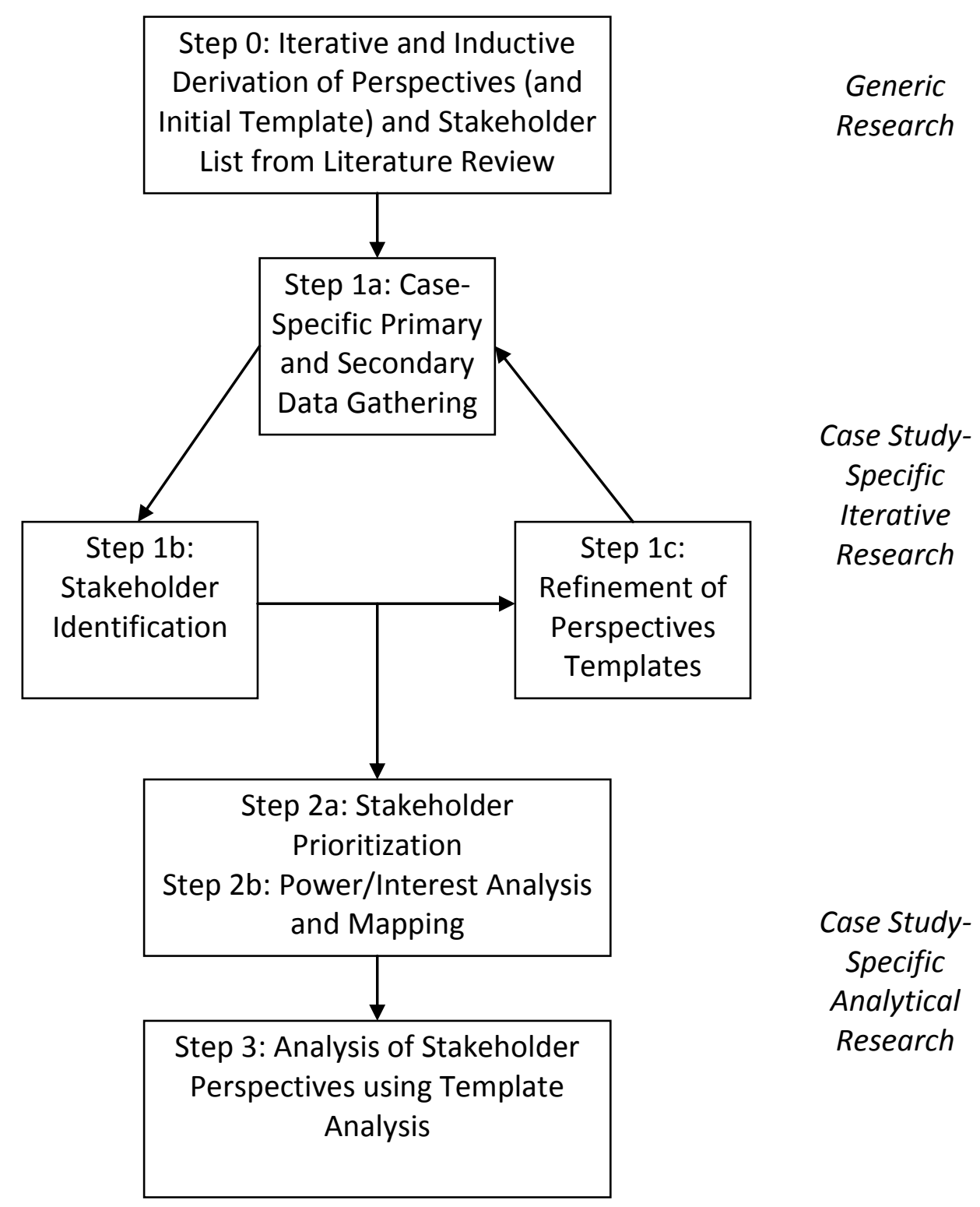

Figure 2: Research Methodology Steps

The question of who is involved with any issue can be addressed via stakeholder analysis (e.g. Savage, Nix, Whitehead, \& Blair, 1991); the means of identifying groups who - in this case - may significantly affect or be significantly affected by open government data (adapting the definition of Freeman, 1984). For analysis of OGD stakeholders, this would involve four elements (developed from Bailur, 2007; Flak \& Rose, 2005):

- Derivation (Step 0 in Figure 2): developing a list of potential stakeholders based on a reading of existing OGD literature. We undertook this inductively and iteratively with the same OGD literature utilized for identification of the perspectives, as cited in Section 
2 , and reaching saturation before that literature was exhausted to identify the following template of potential stakeholder groups: politicians, senior public officials, public sector OGD practitioners, civil society organizations, citizen-users, ICT providers, entrepreneurusers, academics/analysts, international organizations, and international donors. ${ }^{1}$

- Identification (Steps $1 \mathrm{a}$ and $1 \mathrm{~b}^{2}$ ): context-specific data-gathering from primary and secondary sources to see which of the potential stakeholders (plus any others not on the list) were significant actors in the OGD field. Details of data-gathering for the Chile case are given below.

- Prioritization (Step 2a): categorization of stakeholders into primary (directly involved with OGD) and secondary (less directly involved). Primary stakeholders can be distinguished as "those who have formal, official, or contractual relationships and have a direct and necessary ... impact" (Savage, Nix, Whitehead, \& Blair, 1991: 62). In this case, we therefore looked for those stakeholders with a formal, direct and necessary impact on OGD planning and implementation. Others who affect or are affected by OGD but less formally and directly and essentially, will be categorized as secondary.

- Analysis (Step 2b): further data gathering in order to map each stakeholder onto a power-interest grid (see Figure 3, adapted from ODA, 1995 and Scholes, 2001). This shows the level of power a stakeholder has to impact the development and implementation of open government data, and their level of interest in OGD. Mapping is acknowledged as a "matter of judgement" (ibid.: 168) that may be improved by intersubjectivity rather than reliance on a single person: here both authors were involved in discussion and mapping. For power, we made reference to a typical schema of sources of power as a checklist: reward, coercive, legitimate, expert, personal, informational, and affiliative (Heeks, 2006). Level of interest was judged by statements made by or in relation to stakeholders, viewed in terms of a political/public policy sense of interest (Bryson, 2004).

\footnotetext{
${ }^{1}$ We use the term "stakeholder groups" here to acknowledge there may be some internal heterogeneity, but the proposed categories were seen as an appropriate compromise between precision and usability, typical of putting stakeholder theory into practice (e.g. Savage, Nix, Whitehead, \& Blair, 1991).

${ }^{2}$ Steps $1 \mathrm{c}$ and 3 in Figure 2 relate to the template analysis of perspectives, described below.
} 


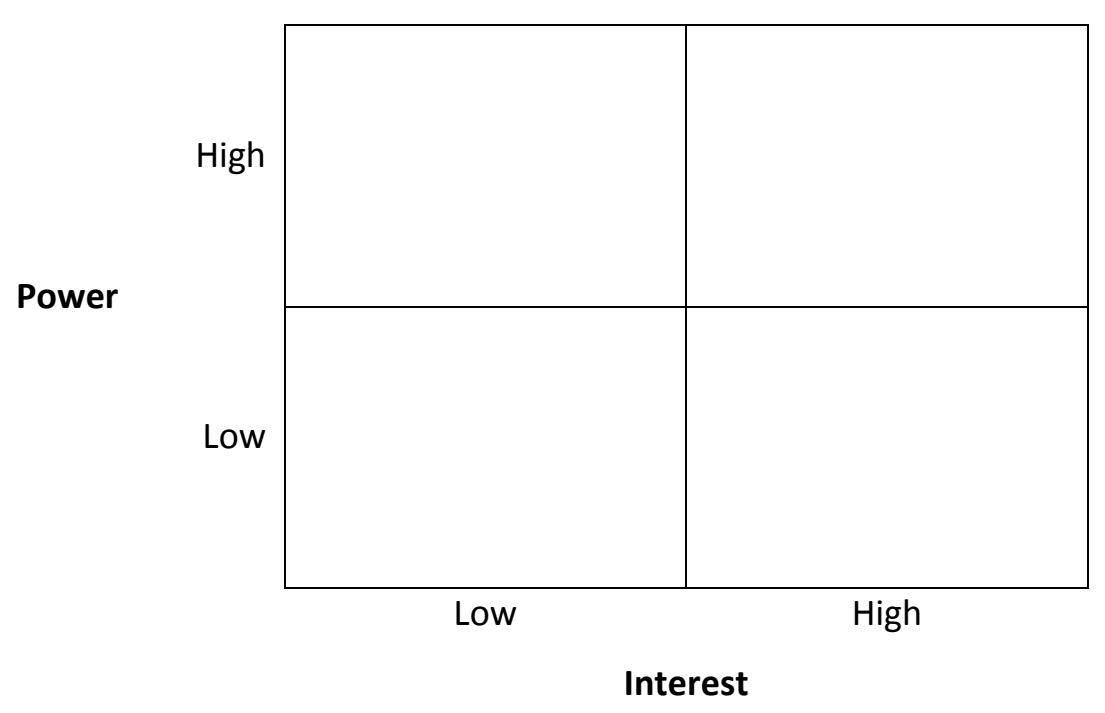

Figure 3: Power-Interest Stakeholder Grid

The question of stakeholder perspectives can be addressed via template analysis (e.g. King, 2012); the means of analyzing text by comparing it to some pre-defined templates which consist of a hierarchical set of thematic codes. In this case, alongside a template for stakeholders, each of the four perspectives identified above was allocated a template ${ }^{3}$. On the basis of the literature cited above, a set of codes was developed that exemplified each of the template-perspectives; essentially a set of unique key textual identifiers that could then be compared to the content of text derived from the field.

This derived text can be drawn from different sources. For a field like OGD involving government activity there may be some preference for documentary sources - policies, reports, papers, public statements - because they provide the best source of clear statements of perspectives which are also readily-accessible, digital-format (hence amenable to computer-assisted content analysis) text. However, as an additional text source and thus providing some triangulation of evidence, interviews or focus groups may also be conducted with key stakeholders (see details below). Template analysis then allows

\footnotetext{
${ }^{3}$ Template analysis is therefore the generic research method through which we undertook perspectives analysis and undertook part of the stakeholder analysis.
} 
for iteration - revision of codes through insertion, deletion, change of scope - during the analysis of the text (King, 2004). By associating revised templates with particular groups, one can get a sense of the different meanings of OGD held by different stakeholders.

\subsection{Chile as an OGD Exemplar}

We chose to instantiate this combined stakeholder/perspectives analysis through an investigation of open government data in Chile. Chile is a country of nearly $18 \mathrm{~m}$ people with a record of economic and political transition. It has changed from a middle-income country with a $40 \%$ poverty rate in the 1980 s to a high-income OECD member today, albeit with significant inequality (Hourton, 2012). During the same period, Chile emerged from nearly two decades of authoritarian rule under General Pinochet to a presidential system and bicameral congressional legislature with a regular and stable series of democratic elections.

We selected Chile because it has followed a pattern fairly typical of many countries around the world in relation to OGD (OGP, 2015b). Like many countries of the global South, Chile has only relatively recently enacted Freedom of Information legislation (Banisar, 2006). Initial laws in 1999 and 2003 related to publication of and access to public documents and records, with constitutional reform and a law in 2005 placing this as a constitutional principle (Vinaixa, 2009). But it was not until 2009 that a revised law came into force specifically on transparency and rights of access to information (CNC, 2009).

From this point, Chile had laid a sufficient foundation to then engage with open government data, creating an OGD portal in 2011 - http://datos.gob.cl; and joining the Open Government Partnership in 2012 as part of the second cohort ${ }^{4}$ (OGP, 2015c). At the time of writing, the OGD portal had in excess of 1,100 datasets available for download. Other OGD activities within government include an open data portal from the Library of the National Congress (http://datos.bcn.cl), an Open Government Action Plan (GDC, 2012b), a Directorate of Active Transparency (http://www.gobiernotransparentechile.cl/) and an Open Government portal (http://www.gobiernoabierto.gob.cl/). This means there were

\footnotetext{
${ }^{4}$ To date, there have been four cohorts of countries joining the OGP; one each in 2011, 2012, 2013 and 2014.
} 
stakeholders across a number of different arms of government alongside others outside government. Organizations of civil society - such as Fundación Ciudadano Inteligente (Smart Citizen Foundation: http://www.ciudadanointeligente.org/) and Derechos Digitales (Digital Rights: http://www.derechosdigitales.org/) - are actively engaged with open government data. International organizations such as the Open Government Partnership were involved; and so were some academics and private sector suppliers.

In all, then, there was sufficient activity around OGD to justify focusing on Chile; the level and timeline of activity was - as noted - similar to a number of the other 65 members of the Open Government Partnership (OGP, 2015b); there were a variety of stakeholders involved; and there was sufficient documentation associated with OGD activity by a number of different stakeholders to enable investigation of perspectives via template analysis.

\subsection{Template Analysis}

The starting point for that template analysis of perspectives was analysis of the literature cited in the previous section, in order to create a foundational code set for each of the four perspectives - bureaucratic, technological, political and economic - represented by the summary in Table 1. Next, and as an iterative process also involving the stakeholder analysis, a search was undertaken in 2013 to identify key OGD documents associated with those stakeholders. Fourteen documents were identified which could form the basis for analysis. As summarized in Appendix 1, these were: a set of Presidential instructions, ten reports (three from public officials, two from public sector OGD practitioners, two from academia, two from international organizations, and one from the private sector), and three conference papers (one from a government official, two from public sector OGD practitioners). All the documents related to either design or implementation of OGD in Chile.

In addition, text was provided from transcripts of the presentations associated with each of the three conference papers, and from four semi-structured interviews conducted in 2013 that discussed OGD's stakeholders, nature, drivers/benefits, and main actors in Chile; issues matching the template headings shown in Table 1. A purposive sampling technique was 
used, selecting an interviewee from each of the key stakeholder groups (Bryman, 2001): a senator with a key role in legislation on public access to information, a public sector manager involved with OGD implementation, a civil society practitioner involved with OGD, and a researcher from an international organization working on open government initiatives.

The text from these various sources was then coded using NVivo10, first to identify match or mismatch to the foundational codes (and, hence, perspectives), and then to revise the code sets for each template-perspective further if necessary. In practice - and reflecting the use of multiple literature sources to create the initial template - the original codes proved to be quite robust, but some revisions are noted in the Conclusions.

\section{Findings}

\subsection{OGD Stakeholders Analysis}

Starting with the initial coding of generic potential stakeholders from the OGD literature, and then instantiating and revising this on the basis of the text (documents, presentations and interviews) analysis, eight main OGD stakeholders were identified in the Chilean context. As summarized next, four were primary stakeholders and four were secondary stakeholders. As discussed in the previous section, primary stakeholders were those with a formal, direct and necessary impact on OGD planning and implementation. Secondary stakeholders were those with informal or non-essential planning and implementation roles in OGD. As discussed below, this division also mapped closely to the power that stakeholders have over OGD.

The primary stakeholders were as follows:

\section{i. Politicians:}

- Legislators: these are deputies and senators from the Chilean Congress; most particularly a few key individuals who have promoted government transparency and 
access to public information. It is they who have helped enact the various items of legislation described above.

- Transparency and Ethics Commission: this is not separate from the previous group, being a body of Congress legislators, but forms the formal collective mechanism for legislation of relevance to open government data to be discussed, proposed and supported. These stakeholders have a high level of power in relation to OGD since they have decisionmaking roles about both the content and presence/absence of OGD legislation (RE3, RE4, CON3, IN2 ${ }^{5}$ ). However, politicians - even though on the Commission - have multiple responsibilities, so the level of interest they can give to any individual issue such as OGD, is rather limited. And there has always been some equivocality among Chilean politicians about the extent to which government data should be opened up, with one impact being legislative delays (Wilson, 2013).

\section{ii. Public Officials:}

- Ministry of the General Secretariat of the Presidency (SEGPRES): responsible for coordination between the administrative and political aspects of the Chilean government, within which sits the unit in charge of planning and implementation of the Chilean OGD agenda.

- Inter-Ministerial Coordination Division of SEGPRES: a committee composed of various ministers who advise the President about government initiatives. This includes discussion of the political and administrative implications of implementing OGD policies within public agencies.

- Transparency Council: an independent body created by the 2009 law on access to public information to oversee compliance with that law by public agencies, and now including compliance with OGD instructions. Although some directors are drawn from outside the civil service, they serve as public officials.

- Presidency of the National Congress: responsible for administration of both houses of the National Congress, including modernization and data management issues; thus covering issues relating to $O G D$ regulation.

\footnotetext{
${ }^{5}$ The sources used are explained in further detail in Appendix 1.
} 
Where the politicians have the highest-level of power in setting the framework for OGD, this group has the highest-level of power in its implementation, and it is they who give the particular shape to Chile's OGD agenda (RE1, RE5, IN1). Because it is their responsibility to implement OGD, they also have a high level of interest.

\section{iii. Public Sector Practitioners:}

- Modernization and Digital Government Unit: located within SEGPRES, this is the administrative unit with specific responsibility for coordination, design and implementation of the OGD agenda, and for ensuring its fulfillment by public agencies. Of all stakeholders, this one represents the heart of OGD in Chile.

- National Congress Library: responsible for publishing all decrees, laws and regulations online, it was a leader in OGD, implementing an agenda of openness prior to the formal adoption of OGD nationally.

If the politicians can be seen to take strategic responsibility for OGD, and the public officials the tactical responsibility, then the public sector practitioners have operational responsibility (RE2, RE3, RE8). They work together with the public officials so there is a mutual shaping between these two groups, but the practitioners are the less powerful of the dyad, and they seemed to have a little less interest, at least in the principles as opposed to practice of OGD (IN1, IN4).

\section{iv. International Organizations:}

- Open Government Partnership (OGP): an alliance of countries who have agreed and adopted the development of an action plan to promote and implement open government, including open government data. As noted above, Chile is an early member and the OGP action plan has shaped Chile's OGD activities.

- World Wide Web Foundation: created by Tim Berners-Lee, this supports openness on the web, considering it to be a global public good and a basic right. The Foundation has provided analysis of and recommendations for implementation of OGD in Chile.

- Organization for Economic Cooperation and Development (OECD): the OECD - to which Chile acceded in 2010 - has provided specific recommendations and guidelines on OGD 
for its member countries, via a specific project based on an earlier analysis and methodology paper (Ubaldi, 2013).

- Economic Commission for Latin America and the Caribbean: this is a UN body working for development of the region, with an open data initiative (http://www.od4d.org/) which includes a particular focus on open government data and which has had active engagement with Chile's OGD initiative.

Particularly because of its relatively-recent emergence from dictatorship to democracy, Chile seems to set quite some store by its membership of international organizations (Altman, Toro, \& Pineiro, 2008). These organizations have therefore been an important shaper of OGD policies, with all of those listed above - particularly the Open Government Partnership within which Chile's "main commitment is the development of an open data agenda" (RE3) - helping determine both the general aims and specific content of OGD in Chile often through formalized agreements or arrangements (RE7, RE10, IN1). Because they sit outside the country, they have less power than the key domestic actors but have been an integral element of OGD in Chile. The specific fractions of these organizations dealing with OGD have a very high level of interest in the topic because it is their sole function to drive forward OGD initiatives (IN4).

The secondary stakeholders, with less direct influence on the content and direction of OGD in Chile but still with a level of involvement were:

\section{v. Civil Society Activists:}

- Transparency Consortium: a consortium of non-profit organizations that seeks to promote transparency, access to public information, and use of that information by citizens.

- Fundación Ciudadano Inteligente (FCI): a key member of the Transparency Consortium, which has sought to promote the Consortium's general agenda via lobbying for policy reforms, technological innovations (e.g. various OGD applications that make use of public data and improve accountability of public officials and agencies), and support for further such innovation within civil society. 
- Derechos Digitales: a non-government organization that focuses on rights within digital environments. Alongside dealing with issues such as online privacy, censorship and copyright, it also includes interests in open data such as OGD.

- Poderopedia: a collaborative platform founded by and working for the media, based upon graphical visualization of open data to understand relationships between politicians, firms and other organizations. A particular initiative is Hackatons (www.hackatons.org; motto "Journalism Needs Nerds"), which seeks to bring journalists and web developers together to help make best use within the media of the open data provided by the Chilean government.

As might be anticipated, these activists have been significantly interested in and engaged with the promotion of OGD in Chile (RE1, IN3, IN4) with, for example, one of the main aims of $\mathrm{FCl}$ being "pushing for the development of transparency and accountability processes, both related to the relationship between money and politics, as well as the civil right to access public information and the implementation of open data policies regarding public data management" (RE4). As just described, that engagement has included promotional activities including workshops, public and online debates, and OGD-related innovation. However, they still remain on the outside of decision-making - with only a "non-binding consultation process" around implementation not the core content of the OGD agenda (RE3) - thus limiting their power to shape Chile's OGD agenda (RE2, RE4, RE7).

\section{vi. Funding Donors:}

- Open Society Foundations (OSF): supported by George Soros, it focuses on creating more open societies, including more open government, and currently provides funding to Fundación Ciudadano Inteligente.

OSF's specific agenda of openness means it is keen to support OGD initiatives (among many other aspects of openness), but as a funder of activism rather than as a direct player, its power to influence OGD in Chile is at arms' length (IN2, IN4). Though not individually identified, other funding donors such as the World Bank and Inter-American Development Bank held some power, though even less direct interest, in relation to open government data via their general interest in transparency (CON1, CON3). 


\section{vii. ICT Providers:}

- Junar: an ICT sector firm founded in Chile but also operating in the US, focused on providing platforms for open data. It has responsibility for implementation of the Chilean government's OGD online platforms.

While Junar does work just within the field of open data, Chilean OGD is just one among a number of its contracts. This relationship is formalized but Junar is substitutable for other supply arrangements, has a purely operational role and thus has somewhat limited power (RE3, IN1).

\section{viii. Academics:}

- Centre for Public Systems, University of Chile: academic centre focused on modernization of the Chilean state through improved policy, design and implementation. It has run some seminars on open government data.

- Centre of Electronic Government, Federico Santa Maria Technical University: research centre taking a socio-technical approach to development of e-government in Chile. It has a research project on open government data.

Although a few local academics have shown some interest on OGD, this was at a formative stage at the time of fieldwork. Reports (e.g. RE1) to date had come from international not local academics, and they had limited influence over OGD in Chile (IN4).

We can summarize this analysis of stakeholders graphically, as shown in Figure 4. 


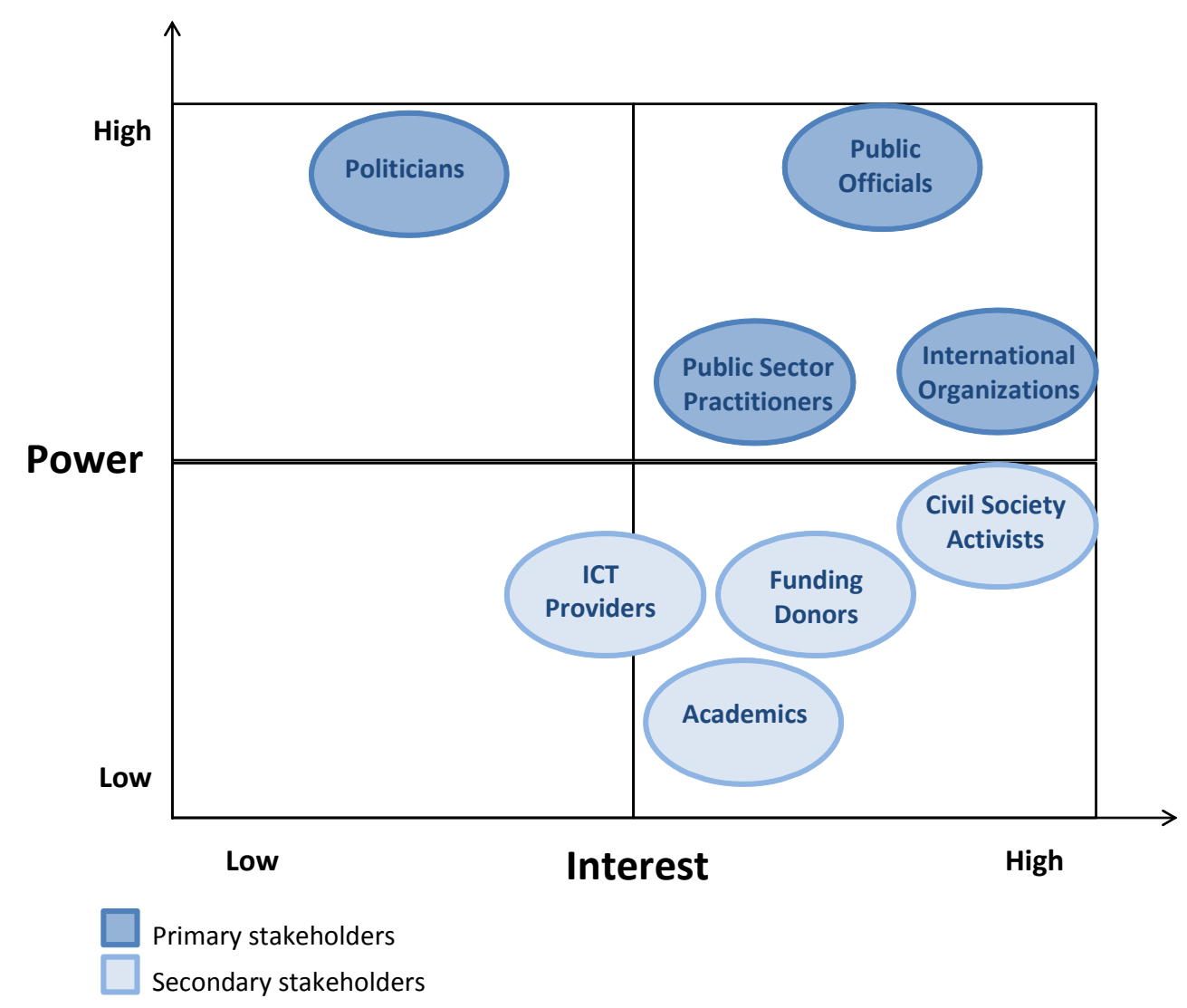

Figure 4: Stakeholder Analysis of Open Government Data in Chile

We can draw two conclusions from the analysis summarized in Figure 4. First, that OGD in Chile has been mostly determined from within government. Second that it has otherwise been shaped rather more by international than national forces. In sum, we might describe this as an "inwards and upwards" pattern of open government data which is likely to shape the perspectives that will dominate in Chile.

We can also note absent stakeholders. Other than Junar and some media and entrepreneur involvement via Hackatons (which have been few in number and small in scale), the local private sector is not an active part of Chilean OGD at present (RE4, RE6, IN1, IN3). This is argued to result from a lack of channels for participation, and also a "lack of motivation" from private firms "fueled partly by the lack of business potential that exists around OGD" (RE10, also IN4). We should also mention multinational firms and investors. Although 
absent from any direct involvement or recognition, they might be awarded a 'tertiary' role because, as seen in other countries' OGD drivers (Elbadawi, 2012), they were an audience to which OGD in Chile was sometimes seen as speaking (CON1, CON2).

Another notable stakeholder, identified in some literature (e.g. Janssen, 2012), absent from this list is citizen-users. It seems that individual citizens are not often users of open government data in Chile, with users more often being organizations of civil society, media and academics (IN4). This might change in future as citizen awareness and connectivity grows but they remain, at present, silent stakeholders; arguably also in the 'tertiary' category due to the indirect nature of their relation to OGD. While often invoked, then, as a rationale behind OGD initiatives, citizen-users may as yet be a rarity, at least in countries of the global South (e.g. Wright, Prakash, Abraham, \& Shah, 2010).

\subsection{OGD Perspectives Analysis}

Having analyzed Chilean open government data's main stakeholders, we now move on to analyze the perspectives expressed by those stakeholders, based around the template summarized in Table 1 and its specific application to text from the OGD sources noted above.

\section{Bureaucratic Perspective}

The strong presence of this perspective, particularly within the highest strategic level of government, is exemplified by the Presidential Instructions on OGD (INS1), which focus on improvements in efficiency and effectiveness of the public sector. This is also a view expressed by practitioners: "the point is how to manage data and therefore how we can take better decisions through OGD, providing customized services" (IN1) so that OGD "improves public service delivery" (RE2, CON1, CON2). Development of OGD in Chile is seen to focus around "an internal challenge" of policy design and inter-agency coordination (CON3) though some also note a reluctance of fellow public servants to share data (IN1). 
This perspective is also shared by some of those outside government. There is acknowledgement that OGD "is not just about citizens or CSOs [civil society organizations], it is also about governments themselves" (RE4, CON2). Some external stakeholders see OGD's capacity to enhance public service delivery (e.g. RE1, IN3) and suggest that it "may lead government to improve the effectiveness of public resources" (RE10) and to "increasing efficiency" of governments (IN4). They also recognize bureaucratic barriers such as poor coordination between public agencies (RE1, IN3). However, as seen below, this must be set alongside expression of other - particularly political - perspectives.

\section{Political Perspective}

This is an important perspective within the Chilean context, and there is some presence within government pronouncements, for example the link to the constitutional right to access public information (Vinaixa, 2009, also IN4) and the action plan to address Open Government Partnership requirements (GDC, 2012a). Public pronouncements may also include mention of "democracy" (CON2) and "citizens' empowerment and participation" (INS1) among other benefits being sought from OGD. But the extent to which this perspective was really "owned" within government was not clear, and it had little if any presence in the text of public sector practitioners relating to implementation (e.g. RE2, IN1). Indeed, when mentioned, there was sometimes acknowledgement that appearance of this perspective was what mattered: "as a country, one of our greatest assets should be to have the image of a transparent country" (CON1).

By comparison there was stronger ownership by external stakeholders. International organizations defined OGD as "a political initiative to achieve new transparency and democracy standards" (RE10, RE7, IN4). As would be expected, local civil society activists whether reported (RE1) or speaking directly (IN3) - were almost entirely rooted in a political perspective. Their guiding interest in democratic change led them to see citizens as the cardinal beneficiaries, see political empowerment and participation as core goals for open government data, and understand barriers to OGD as deriving from political resistance within government. Within academic reports also, there was a focus on OGD's potential importance in inducing democratic change within Chile (RE1, RE4). 


\section{Technological Perspective}

At least in the sources gathered for analysis in this research, there was little reflection of a technological perspective. This would be anticipated from a number of the stakeholders who did not have strong technical capacities or components in their work. But it was also seen from public sector practitioners, some of whom explicitly rejected a technological perspective: "OGD is about people ... and not about platforms or standards" (CON1, also RE2, IN1). Similarly, those outside government who spoke about this recognized OGD's implicit requirement for technological innovation around data standards and dissemination (IN3, IN4). However, they pushed technology away from center stage, assigning it a peripheral enabling role rather than a core functionality. While technological issues such as data interoperability are acknowledged, they are seen - at least relative to bureaucratic and political barriers - as reasonably straightforward to address (IN1, IN4).

\section{Economic Perspective}

Expression of the economic perspective as per the template was seen even less than for the technological perspective. While international organizations note the general potential for creation of external economic value from public data (RE7, RE10), there is no mention of this in the Presidential Instructions on open government data (INS1). The same view is shared at the practitioner level, with an economic perspective on OGD absent from documentation, and confirmed that "we do not have particular strategies about OGD with economic objectives" (IN1). As might be expected, OGD activists within civil society do not express an economic perspective either: they see that involvement of individual entrepreneurs can foster the innovations necessary to enable OGD (as in the Hackaton events) but do not present the reverse flow of OGD fostering private sector growth (RE1, RE4, IN3). The only direct expression therefore comes from the private firm, Junar, involved with supporting the OGD platform (RE4).

Lack of visibility for this direct economic view of OGD in Chile is a manifestation of the stakeholder analysis outlined above: the private sector has been barely represented in the discourse or design or implementation of open government data (RE9). There is a "chicken- 
and-egg" aspect to this: low OGD-related awareness and capacity within the private sector means firms have not pushed themselves forward into the OGD arena to express a perspective (RE10, IN4). However, there was an indirect economic perspective occasionally visible: seeing OGD as a means to transmit an external vision of Chile as a transparent and stable country, with an external financial audience - donors, multinationals, investment banks, sovereign funds - in mind (CON1, CON2).

\section{Discussion and Conclusions}

\subsection{Discussion}

Reviewing the findings, there is a dominance of the bureaucratic and political perspectives. The technological and economic perspectives are present but they are not really incorporated into the mainstream discourse around policy and strategy on open government data in Chile. This reflects the lack of voice for technical experts and private firms within the debate, and there is a path dependency and circular reinforcement here.

Power and, to some extent, expertise around OGD resides within the primary stakeholders who express bureaucratic and political views (CON3, IN1). Initial politico-bureaucratic dominance means technical and economic views are not prioritized for participation in OGD discussions and planning, so those views do not emerge much within OGD debate nor do they shape the design of OGD (RE10, IN4). Three consequences can be observed. The focus on data accessibility has not yet been matched by an equal concern for improvements in data quality and data integration. There is little sign of entrepreneurial creation of new OGD-based products, services or jobs. And actors with technological or economic views likely feel a lack of validation or motivation to become involved in future (IN4).

Looking at the two principal perspectives, there is the sense of a mirror image. The bureaucratic perspective seems strongest within government and is shared to some degree by international organizations and local activists. The political perspective seems strongest 
outside government via international organizations and local activists, and is shared to some degree by government stakeholders.

Of the two, the former was perhaps the more dominant. At least, we can say that in almost all of the text relating to OGD in Chile, there was a sense that government was the "sun" and others were just "planets"; that the most-readily accepted perspective was one that placed government bureaucracy at the center. Although this was not quite as specific as the focus on just public servants and ICT staff suggested in the original template, it does gel with the idea expressed earlier of a somewhat inward-looking view of OGD.

Additionally, it could be argued that the political perspective reflected aspiration while the bureaucratic perspective reflected reality. Right across the spectrum of sources and stakeholders (e.g. RE1, RE4, RE5, RE10, INS1, CON2, IN1, IN3, IN4), one can find examples of OGD in Chile being at least partly framed in political terms as a tool for citizen empowerment. That represents its potential.

The reality was that progress had so far been largely made in bureaucratic terms with the formulation of government policies and regulations and processes, the production of datasets, and reporting to the Open Government Partnership, but not much more than this (RE1, RE10, CON1, IN2, IN3). As the international organization researcher commented, "impact on [citizen] beneficiaries is still marginal and not many people know what OGD is" (IN4). This matches the idea of citizens as silent stakeholders: those with the political perspective claim to act for citizens or on their behalf but actual use of OGD has only trickled down to a few intermediary organizations, with citizens largely absent; lacking either direct "voice" that inputs to OGD or direct "hands" that make use of OGD outputs.

This reinforces the picture painted from the stakeholder analysis of an OGD experience as yet largely oriented "inwards and upwards" rather than "outwards and downwards". This is not full-scale "openwashing" - a mere pretense at openness (Yehuda, 2011) - since government clearly has delivered a whole series of available datasets. However, as yet, the rhetoric of the political perspective is running well ahead of the reality. 
This exemplifies a broader issue that all the OGD perspectives have some design-reality gap in the Chilean context: a gap between their design objectives and the current state of implementation (Heeks, 2006). Alongside citizen empowerment then - significant improvements in public services; the notion of a free-flowing digital infrastructure; the liberation of economic value from government data - all these remain aspirations more than facts in Chile (RE1, CON3, IN2, IN3, IN4). One reason is the data-centricity of all the perspectives.

We can understand this better via a basic information value chain model, as shown in Figure 5 (adapted from Heeks \& Kanashiro, 2009).

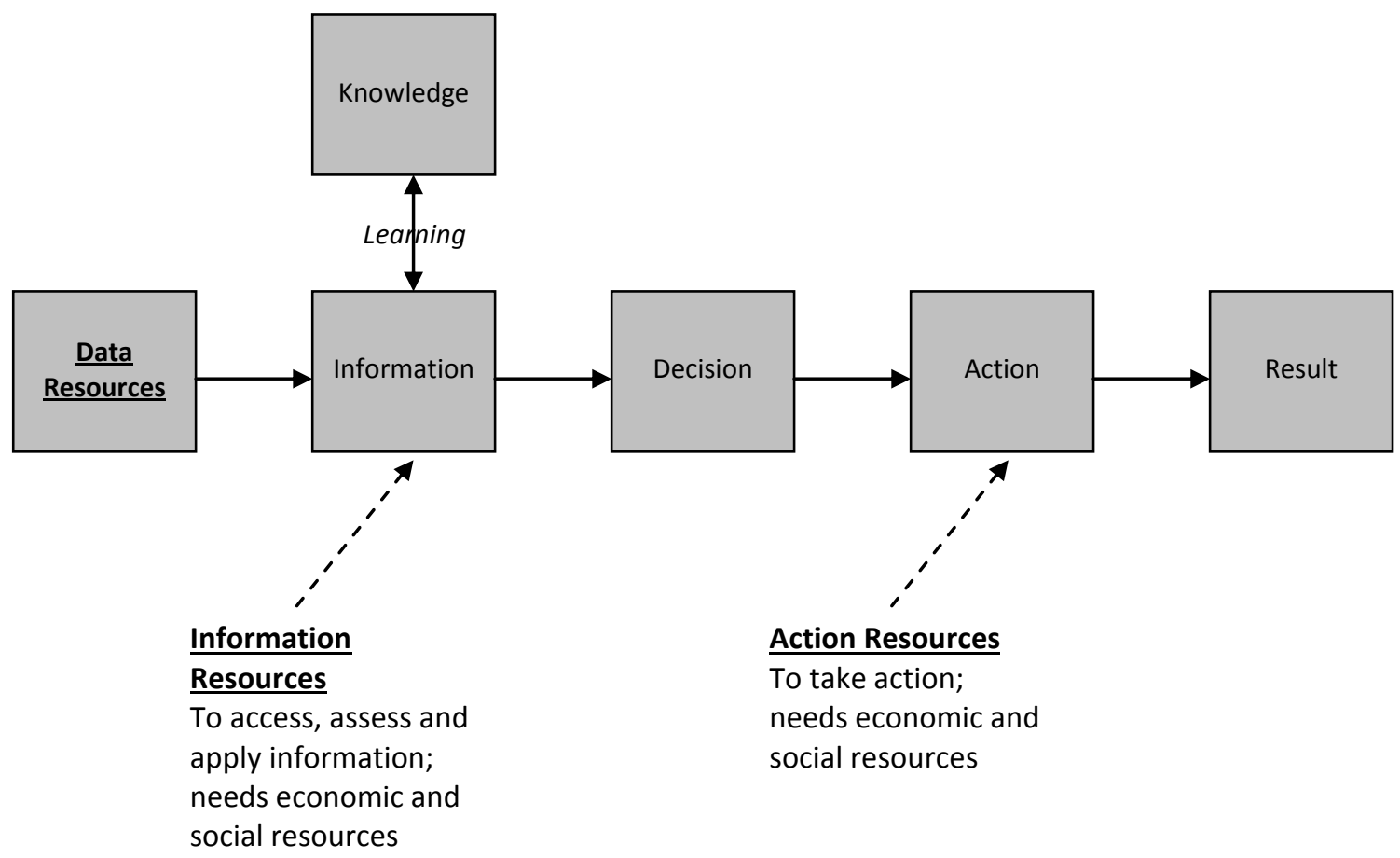

Figure 5: The Information Value Chain

In their drivers and benefits, the perspectives expressed in Chile tend to focus on a set of end results; the last link in the chain. But in their detail, the perspectives focus more on the first link in the chain: provision of data. The perspectives have said much less about the intervening steps: i.e. how OGD is converted into information (a step requiring resources 
such as awareness, ICT literacy, motivation, confidence, knowledge); how decisions can be made by OGD users on the basis of that information; and how those decisions are converted into actions (which again may require resources like time, money, skills, power, motivation, etc.). These were occasionally implicitly acknowledged (IN3, IN4) but the gap between data and results was not explicitly framed in the current sources, and so - at least in the Chilean context - there is a "missing middle" within most expressions of OGD perspectives; a hollowed-out approach that insufficiently incorporates the gap between a reality of data provision and an aspiration of developmental results.

In part, this may be a product of the relative recency of OGD in the country, with data publication being the first step along the information value chain, and with later steps only following once the first step is firmly in place. However, we must also acknowledge Chile's history and the way in which this shapes the context of politics, institutions, capabilities and interests within which OGD is being planned and implemented. In particular, the 17 years of dictatorship up to 1990 have cast a long shadow.

On the one hand, during the post-1990 period of democratic transition, Chilean governments have been keen to demonstrate their break from the era of dictatorship. They have placed a strong emphasis on broadcasting signals of democracy, particularly to the outside world and most particularly in the hope of attracting foreign investments which are seen as vital to economic growth and fiscal health in Chile (Castañeda, 2013; Salcedo \& Akoorie, 2013). Government's embrace of OGD can partly be understood in this light and, as noted, is partly stated in this light (e.g. CON1, CON2). In facing "upwards" to an audience of foreign governments or investors, what matters most is an appearance of transparency. This can be satisfied by the presence of datasets, some political perspective rhetoric in pronouncements, and membership of the Open Government Partnership and adherence to its minimum standards. This is not to say that government stakeholders care nothing for the "missing middle" and delivery of results; simply that the external audience-related incentives are much stronger for appearance than fulfillment. 
On the other hand, even after 25 years, Chile is still a country in transition from dictatorship to democracy. Power remains quite strongly concentrated within central government and civil society remains relatively weak (RE1, IN4, Aninat, Landregan, Navia, \& Vial, 2006; Oxhorn, 2011). Thus the bureaucratic processes and interests of central government tend to dominate implementation while the political interests of civil society tend to remain sidelined (RE10, CON3, IN1) ${ }^{6}$. Within government at least, we therefore see the political perspective stronger for "upwards" messages around the values of OGD, and the bureaucratic perspective stronger for "inwards" messages around the administration and implementation of OGD. Yet the inward nature of the bureaucratic perspective, reflected in the inertia and even resistance to change described above, could explain its expression far more around data management than around the later steps in the information value chain that would lead to significant improvements in public service delivery. Changing that perspective to get public servants to make the connections from data to public service improvements would require administrative interventions that built expertise, but also much more challenging political and cultural interventions that sought to change the landscape of power and institutional forces within government (Davies \& Bawa, 2012; Janssen, Charalabidis, \& Zuiderwijk, 2012).

\subsection{Conclusions}

Open government data is akin to a country fair, drawing travelers from different origins via different paths and vehicles to all end up currently parked in one place. It is valuable to dig behind their co-location and find ways to expose their different identities and values.

Stakeholder analysis and perspective analysis have both proven to be useful in doing this, thus helping us to understand open government data and to address our three initial questions. Answering the first question by identifying OGD stakeholders - including categorization into primary and secondary stakeholders, and by power and interest - was relatively straightforward, though care was needed to acknowledge absent stakeholders. The four perspectives derived from the literature - bureaucratic, technological, political and

\footnotetext{
${ }^{6}$ As also does discussion of OGD within local as opposed to central government.
} 
economic - were valuable starting points in answering the second question on different stakeholder meanings, though some modifications did emerge. Analysis of both political and bureaucratic perspectives highlighted the need to understand a perspective expressed as rhetoric or aspiration versus a perspective expressed as a reflection of implemented reality. Although hardly explicitly present in the texts used here, there are signs of a politico-economic perspective: one that uses OGD as a signal of political openness and democratic stability in order to attract economic investment from foreign companies and governments. But these were modifications rather than refutations of the founding perspectives.

From the discussion above, we can extract three other dimensions that address the third question and add further insight to help explain the different meanings of OGD that stakeholders adopt:

- Capacities: the ability of particular stakeholders to engage with OGD and with the debate on OGD will depend on their capacities. These include their awareness of OGD; the resources they have to turn data into information, information into decisions, and decisions into actions as per the information value chain; and the relative balance of their social, socio-technical, and technical abilities. These also include the capacity of power: the ability of particular stakeholders to have their perspective on OGD prevail.

- Incentives: each stakeholder brings to the arena of open government data a particular set of motivations and interests that will guide their view of, and engagement with, OGD.

- Context: the history, politics and institutions of each specific context significantly shape the OGD-relevant capacities and incentives that stakeholders have.

The specific findings presented here - the identity and categorization of OGD stakeholders, the nature and balance of the meanings they give to OGD, and the explanation for those perspectives - were all unique to Chile, and provide no basis for generalization to other countries. But we hope what can be generalized to other countries is the approach stakeholder analysis and perspectives analysis undertaken via the methodological steps and tools outlined in this paper - as a means to understand OGD in any context. 
At the time of fieldwork, open government data was only two years old in Chile as an explicit concept. The number of OGD documents and stakeholders was rather limited, and this also limited the extent of available text for analysis. Future research work can therefore not only analyze the meanings of OGD in other countries, but also return to Chile at a later date. This timing must also be factored in to the analysis: the data-centricity of expressed perspectives and limited progress along the information value chain could be typical of any country in the early stages of open government data.

Overall, we hope that the investigation here has been sufficient to demonstrate the value of this type of analysis. We see this as a necessary foundation for not just researchers but also practitioners seeking to engage with any national OGD context: a necessity to understand who the key actors are, what different meanings they bring to OGD, and why they have those different meanings. Using the analysis approach outlined above, they will understand if key stakeholders are absent, the relative balance of prominence of different perspectives, and the implications thereof. This will allow any OGD actor to better understand not only those they seek to work with, but also themselves. It will also allow them to better participate in both planning and implementation of OGD, understanding everything from the type of language best adopted in order to engage particular groups, to the limitations that may constrain some OGD recommendations.

\section{References}

AIE/OKF (2011). Beyond Access: Open Government Data and the Right to (Re)use Public Information, Access Information Europe \& Open Knowledge Foundation http://www.accessinfo.org/documents/Access Docs/Advancing/Beyond Access 7 January 2011 web.pdf

Altman, D., Toro, S. \& Pineiro, R. (2008). International Influences on Democratic Transitions: the Case of Chile, Working Paper No. 86. Stanford, CA: Center on Democracy, Development, and the Rule of Law, Stanford University. 
Aninat, C., Landregan, J., Navia, P. \& Vial, J. (2006). Political Institutions, Policymaking Processes and Policy Outcomes in Chile. Washington, DC: Inter-American Development Bank.

Axelsson, K., Melin, U. \& Lindgren, I. (2013). Public e-services for agency efficiency and citizen benefit: findings from a stakeholder centered analysis, Government Information Quarterly, 30(1), 10-22.

Bailur, S. (2007). Using stakeholder theory to analyze telecenter projects, Information Technologies and International Development, 3(3), 61-80.

Banisar, D. (2006). Freedom of Information Around the World 2006. Washington, DC: freedominfo.org.

Barros, A. (2011). Open data: nuevo paradigma en el manejo de datos, Revista Bits de Ciencia, 6(2), 25-28.

Basoalto, R. (2012). Open Government Data in Chile; MSc thesis. Santiago, Chile: School of Engineering, Pontificia Universidad Católica de Chile.

Bates, J. (2012). "This is what modern deregulation looks like": co-optation and contestation in the shaping the UK's Open Government Data Initiative, Journal of Community Informatics, 8(2). http://www.ci-journal.net/index.php/ciej/article/view/845/916

Braunschweig, K., Eberius, J., Thiele, M. \& Lehner, W. (2012). The state of open data: limits of current open data platforms, paper presented at WWW2012, Lyon, France, 16-20 Apr.

Bryman, A. (2001). Social Research Methods. Oxford, UK: Oxford University Press.

Bryson, J.M. (2004). What to do when stakeholders matter, Public Management Review, 6(1), 21-53. 
Bustamante, A. (2013). Plenario de Planes de Acción para OGP. Santiago, Chile: Regional Open Government Partnership Summit. https://www.youtube.com/watch?v=t1cNaKmlz9w

Bustamente, A. \& Mancini, F. (2012). El camino del gobierno abierto en Chile, Revista Bits de Ciencia, 7(1), 21-25.

Cabinet Office (2012). Open Data White Paper. London, UK: Cabinet Office.

Capgemini Consulting (2013). The Open Data Economy. Utrecht, The Netherlands: Capgemini Consulting.

Castañeda, F. (2013). El superávit fiscal estructural en Chile, Políticas Públicas, 1(1), 71-84.

Chiaretti, A. (2013). Datos abiertos (enlazados) y democratización del acceso a la información en Chile. Proceedings of 14th International Knowledge Conference, Universidad de Chile, Santiago, Chile, 7-10 Jan.

CNC (2009). Ley de Acceso a la Información Pública. Santiago, Chile: Congreso Nacional de Chile.

Concha, G., \& Naser, A. (2012a). Datos Abiertos: Un Nuevo Desafío para los Gobiernos de la Región. Santiago, Chile : ECLAC-UN.

Concha, G., \& Naser, A. (2012b). El Desafío hacia el Gobierno Abierto en la Hora de la Igualdad. Santiago, Chile : ECLAC-UN.

Davies, T. (2010). Open Data, Democracy and Public Sector Reform.

http://www.opendataimpacts.net/report/ 
Davies, T., \& Bawa, Z.A. (2012). The promises and perils of open government data, Journal of Community Informatics, 8(2). http://ci-journal.net/index.php/ciej/article/view/929/955

Ding, L., Michaelis, J., McGuinness, D.L. \& Hendler, J. (2010). Making sense of open government data, paper presented at Web Science Conference 2010, Raleigh, NC, 26-27 Apr.

Elbadawi, I.A. (2012). The state of open government data in GCC countries, in: Proceedings of the $12^{\text {th }}$ European Conference on e-Government, M. Gasco (ed). Reading, UK: Academic Publishing International, 193-200.

Ferreiro, A. (2013). El Acceso a la Información Pública en la Agenda de OGP. Santiago, Chile: Regional Open Government Partnership Summit.

https://www.youtube.com/watch?v=z6VJcsccPVc

Ferreiro, S. (2012). La promesa de los datos abiertos enlazados, paper presented at Seminario Internacional sobre Transparencia y Probidad en el Congreso Nacional y el Sistema de Partidos Políticos, Santiago, Chile, 12 Jan.

http://www.bcn.cl/seminarios actividades/evento.html?h=10221.1/27056\&hs=10221.1/27 $\underline{048}$

Flak, L.S., \& Rose, J. (2005). Stakeholder governance: adapting stakeholder theory to egovernment, Communications of the Association for Information Systems, 16, 642-664.

Freeman, R.E. (1984). Strategic Management: A Stakeholder Approach. Boston, MA: Pitman Publishing.

GDC (2012a). Plan Estratégico de Gobierno Electrónico. Santiago, Chile: Gobierno de Chile. http://www.observatoriodigital.gob.cl/sites/default/files/plan_estrategico_gobierno_digital 2011-2014.pdf 
GDC (2012b). Alianza para el Gobierno Abierto: Plan Accion del Gobierno de Chile. Santiago, Chile: Gobierno de Chile.

http://www.opengovpartnership.org/sites/default/files/legacy files/Chile\%20National\%20P $\underline{\text { lan.pdf }}$

GDC (2012c). Instructivo Presidencial Nro 5 sobre Gobierno Abierto. Santiago, Chile:

Gobierno de Chile. http://www.gobiernoabierto.cl/sites/default/files/gab.pres.ndeg005.pdf

Heeks, R. (2006). Implementing and Managing eGovernment. London, UK: Sage Publications.

Heeks, R., \& Kanashiro, L.L. (2009). Remoteness, Exclusion and Telecentres in Mountain Regions: Analysing ICT-Based "Information Chains" in Pazos, Peru, IDPM Development Informatics Working Paper no.38. Manchester, UK: University of Manchester.

Heusser, F.I. (2013). Understanding OGD and Addressing its Impact. Santiago, Chile: OD4D.

Hourton, A. (2012). Income Inequality in Chile: 1990-2006, GSE Discussion Paper no.E-12004. Kyoto, Japan: Kyoto University.

Howard, A. (2012a). No joke: open data fuels transparency, civic utility and economic activity, govfresh, 2 May. http://gov20.govfresh.com/no-joke-open-data-fuels-transparencycivic-utility-and-economic-activity/

Howard, A. (2012b). Data for the Public Good. Sebastopol, CA: O’Reilly Media.

Huijboom, N., \& van den Broek, T. (2011). Open data : an international comparison of strategies, European Journal of ePractice, 12(2), 1-13.

Inria (2013). El Open Data se Proyecta Como una Nueva Plataforma de Negocios y una Mejor Democracia en Chile. Santiago, Chile: Inria. http://www.ciric.cl/wpcontent/uploads/2012/12/Comunicado-Open-Data.pdf 
Janssen, K. (2012). Open government data and the right to information : opportunities and obstacles, Journal of Community Informatics, 8(2), 1-11.

Janssen, M., Charalabidis, Y. \& Zuiderwijk, A. (2012). Benefits, adoption barriers and myths of open data and open government, Information Systems Management, 29(4), 258-268.

Janssen, M., \& Zuiderwijk, A. (2014). Infomediary business models for connecting open data providers and users, Social Science Computer Review, 32(5), 694-711.

Kalampokis, E., Tambouris, E. and Tarabanis, K. (2011). Open government data: a stage model, Lecture Notes in Computer Science: Electronic Government, 6846, 235-246.

Kassen, M. (2013). A promising phenomenon of open data, Government Information Quarterly, 30(4), 508-513.

King, N. (2004). Using templates in the thematic analysis of text, in: Essential Guide to Qualitative Methods in Organizational Research, C. Cassell \& G. Symon (eds). London, UK: Sage Publications, 256-270.

King, N. (2012). Doing template analysis, in: Qualitative Organizational Research, . In G. Symon \& C. Cassel (eds). London, UK: Sage Publications, 426-250.

Lathrop, D., \& Ruma, L. (2010). Open Government: Collaboration, Transparency and Participation in Practice. Sebastopol, CA: O’Reilly Media.

Longo, J. (2011). \#OpenData: Digital-era governance thoroughbred or new public management Trojan horse?, Public Policy and Governance Review, 2(2), 38-52.

Luna-Reyes, L.F., Bertot, J.C., \& Mellouli, S. (2014). Open government, open data and digital government, Government Information Quarterly, 31(1), 4-5. 
Malmud, C., et al (2007). Open Government Data Principles.

https://public.resource.org/8 principles.html

Meijer, A.J., Curtin, D. \& Hillebrandt, M. (2012). Open government: connecting vision and voice, International Review of Administrative Sciences, 78(1), 10-29.

Obama, B. (2010). Transparency and Open Government, Presidential Memorandum. Washington, DC: The White House.

ODA (1995). Guidance Note on how to do Stakeholder Analysis of Aid Projects and Programmes. London, UK: Overseas Development Administration.

OGP (2012). The Case of Chile: From the Secret State to the Open State San Francisco, CA: Open Government Partnership. http://www.opengovpartnership.org/news/case-chilesecret-state-open-state

OGP (2015a). About. San Francisco, CA: Open Government Partnership. http://www.opengovpartnership.org/about

OGP (2015b). Participating Countries. San Francisco, CA: Open Government Partnership. http://www.opengovpartnership.org/countries

OGP (2015c). Chile. San Francisco, CA: Open Government Partnership. http://www.opengovpartnership.org/country/chile

Otjacques, B., Hitzelberger, P. \& Feltz, F. (2007). Interoperability of e-government information systems: issues of identification and data sharing, Journal of Management Information Systems, 23(4), 29-51. 
Oxhorn, P. (2011). Sustaining Civil Society: Economic Change, Democracy, and the Social Construction of Citizenship in Latin America. University Park, PA: Pennsylvania State University Press.

Precht, A. \& Huerta, H. (2011). Gobierno abierto: la experiencia de Chile, in: La Promesa del Gobierno Abierto, A. Hofmann, A.R. Alujas \& J.A.B Pereznieto (eds). Villahermosa: Mexico, 401-420.

http://inicio.ifai.org.mx/Publicaciones/La\%20promesa\%20del\%20Gobierno\%20Abierto.pdf

Raman, B. (2012). The rhetoric and reality of transparency, Journal of Community Informatics, 8(2). http://ci-journal.net/index.php/ciej/article/view/866/909

Robinson, D., Yu, H., Zeller, W. \& Felten, E. (2009). Government data and the invisible hand, Yale Journal of Law and Technology, 11, 160-175.

Saebo, O., Flak, L.S. \& Sein, M.K. (2011). Understanding the dynamics in e-participation initiatives: looking through the genre and stakeholder lenses, Government Information Quarterly, 28(3), 416-425.

Salcedo, C., \& Akoorie, M. (2013). Foreign direct investment in Chile: historical process, changing political ideologies and the responses of MNEs, AD-Minister, 23, 103-129.

Savage, G.T., Nix, T.W., Whitehead, C.J. \& Blair, J.D. (1991). Strategies for assessing and managing organizational stakeholders, Academic of Management Executive, 5(2), 61-75.

Scholes, K. (2001). Stakeholder mapping, in: Exploring Public Sector Strategy, G. Johnson \& K. Scholes (eds). Harlow, UK: Pearson Education, 165-184.

Thompson, C. (2011). How information can fuel jobs, Wired, 29 Mar. http://www.wired.com/2011/03/st thompson free data/ 
Ubaldi, B. (2013). Open Government Data: Towards Empirical Analysis of Open Government Data Initiatives. Paris, France: OECD.

United Nations (2013). Open Government Data for Citizen Engagement in Managing Development Guidance Toolkit. New York, NY: United Nations.

Vinaixa, J.P. (2009). Ley de Transparencia y Acceso a la Información Pública, paper presented at XIV Conferencia Internacional de Bibliotecología, Santiago, Chile, 2-4 Nov. http://www.bibliotecarios.cl/descargas/2009/10/poblete.pdf

Wilson, J.M. (2013). Informe del gobierno advierte retraso del Congreso en leyes de transparencia, La Tercera, 29 Jul.

World Bank (2012). From Open Government Data to Social Accountability. Washington, DC: World Bank.

Wright, G., Prakash, P., Abraham, S. \& Shah, N. (2010). Open Government Data Study: India. London, UK: Transparency \& Accountability Initiative. http://www.transparencyinitiative.org/wp-content/uploads/2011/05/open data india final1.pdf

WWW Foundation (2011). Open Government Data: Feasibility Study in Chile. Washington, DC: World Wide Web Foundation.

Yehuda, G. (2011). OpenWashing doesn't really work, Being Open With You blog, 6 Jan. http://www.gilyehuda.com/2011/01/06/openwashing-doesnt-really-work/

Yu, H., \& Robinson, D.G. (2012). The new ambiguity of "open government", UCLA Law Review Discourse, 52(11), 178-208. 
Zuiderwijk, A., \& Janssen, M. (2012). Impediments, challenges and recommendations for using open government data, paper presented at Using Open Data, Brussels, Belgium, 19-20 Jun. 
Appendix 1: Data Sources

\begin{tabular}{|c|c|c|c|c|}
\hline Code & Year & Type of source & $\begin{array}{c}\text { Stakeholder } \\
\text { (Author / } \\
\text { Presenter / } \\
\text { Interviewee) }\end{array}$ & Reference \\
\hline RE1 & 2012 & Report & Academic & $\begin{array}{l}\text { Basoalto (2012) - Open Government Data in } \\
\text { Chile }\end{array}$ \\
\hline RE2 & 2012 & Report & $\begin{array}{l}\text { Public Sector } \\
\text { Practitioner }\end{array}$ & $\begin{array}{l}\text { GDC (2012a) - Plan Estratégico de Gobierno } \\
\text { Electrónico }\end{array}$ \\
\hline RE3 & 2012 & Report & Public Official & $\begin{array}{l}\text { Bustamante \& Mancini (2012) - El Camino } \\
\text { del Gobierno Abierto en Chile }\end{array}$ \\
\hline RE4 & 2013 & Report & Academic & $\begin{array}{l}\text { Chiaretti (2013) - Datos Abiertos (Enlazados) } \\
\text { y Democratización del Acceso a la } \\
\text { Información en Chile }\end{array}$ \\
\hline RE5 & 2011 & Report & Public Official & $\begin{array}{l}\text { GDC (2012b) - Alianza para el Gobierno } \\
\text { Abierto: Plan Accion del Gobierno de Chile }\end{array}$ \\
\hline RE6 & 2011 & Report & Public Official & $\begin{array}{l}\text { Precht \& Huerta (2011) - Gobierno Abierto: } \\
\text { La Experiencia de Chile }\end{array}$ \\
\hline RE7 & 2012 & Report & $\begin{array}{l}\text { International } \\
\text { Organization }\end{array}$ & $\begin{array}{l}\text { OGP (2012) - The Case of Chile: From the } \\
\text { Secret State to the Open State }\end{array}$ \\
\hline RE8 & 2012 & Report & $\begin{array}{l}\text { Public Sector } \\
\text { Practitioner }\end{array}$ & Provided on condition of confidentiality \\
\hline RE9 & 2012 & Report & ICT Provider & $\begin{array}{l}\text { Inria (2012) - El Open Data se Proyecta } \\
\text { Como una Nueva Plataforma de Negocios y } \\
\text { una Mejor Democracia en Chile }\end{array}$ \\
\hline RE10 & 2011 & Report & $\begin{array}{l}\text { International } \\
\text { Organization }\end{array}$ & $\begin{array}{l}\text { WWW Foundation (2011) - Open } \\
\text { Government Data: Feasibility Study in Chile }\end{array}$ \\
\hline INS1 & 2012 & $\begin{array}{l}\text { Presidential } \\
\text { Instructions }\end{array}$ & Politician & $\begin{array}{l}\text { GDC (2012c) - Instructivo Presidencial No } 5 \\
\text { sobre Gobierno Abierto }\end{array}$ \\
\hline CON1 & 2012 & $\begin{array}{l}\text { Conference } \\
\text { Paper/Presentation }\end{array}$ & $\begin{array}{l}\text { Public Sector } \\
\text { Practitioner }\end{array}$ & $\begin{array}{l}\text { Ferreiro (2012) -La Promesa de los Datos } \\
\text { Abiertos Enlazables }\end{array}$ \\
\hline CON2 & 2013 & $\begin{array}{l}\text { Conference } \\
\text { Paper/Presentation }\end{array}$ & $\begin{array}{l}\text { Public Sector } \\
\text { Practitioner }\end{array}$ & $\begin{array}{l}\text { Bustamante (2013) - Plenario de Planes de } \\
\text { Acción para OGP }\end{array}$ \\
\hline CON3 & 2013 & $\begin{array}{l}\text { Conference } \\
\text { Paper/Presentation }\end{array}$ & Public Official & $\begin{array}{l}\text { Ferreiro (2013) - El Acceso a la Información } \\
\text { Pública en la Agenda de OGP }\end{array}$ \\
\hline IN1 & 2013 & Interview & $\begin{array}{l}\text { Public Sector } \\
\text { Practitioner }\end{array}$ & \\
\hline IN2 & 2013 & Interview & Politician (Legislator) & \\
\hline IN3 & 2013 & Interview & Civil Society Activist & \\
\hline IN4 & 2013 & Interview & $\begin{array}{l}\text { International } \\
\text { Organization }\end{array}$ & \\
\hline
\end{tabular}

